\title{
On gravel - socio-material objects of northern development
}

\author{
Kirsty Howey \\ Department of Gender and Cultural Studies, University of Sydney \\ kirstyhowey@hotmail.com
}

Keywords: Development; Socio-Material Objects; Settler-Colonial Relations; Property; Land Tenure

\begin{abstract}
Wealth from extractive development has been at the forefront of political aspirations for the Northern Territory of Australia (NT), and of northern Australia more broadly, for many decades. According to political, bureaucratic and industry rhetoric, the north is insufficiently developed to reach its full potential. The most recent iteration of this development agenda has been catalysed by the Commonwealth Government's White Paper on "Developing the North". Eschewing the usual frames for analysing 'development,' this paper proposes that northern development can be seen as a going on together doing differences with development "objects.' It mobilises a ground-up STS to understand what such objects are in an unorthodox way, as socio-material entities.
\end{abstract}

The entities the paper focuses on are gravelly; gravelly roads, and legal contracts that concern gravel. Northern development certainly requires that these two entities, very different though they are, must go on together. But seeing that necessity, we also see that a third gravelly entity, often obscured, needs to be foregrounded to understand what is also at stake in northern development projects. The 'people-places' that are gravel pits need to be explicitly involved as objects if northern development is to be inclusive, and is to disrupt the dominant power relations within which it is enmeshed.

As socio-material entities, the places that are the gravel pits, intimately involved with gravelly roads and legal contracts, are about gravel supply. Yet they are owned by Indigenous landowners. These places are constituted in quite different institutions, alternative and diverse languages, and in disparate knowledge traditions, compared with those that constitute the gravelly roads, and the legal contracts concerning gravel. The paper argues that all three are 'northern development objects,' and all need to be involved in northern development policy.

\section{Introduction: on gravel}

In recent years, buoyed by the release by the federal Coalition government of a 'White Paper' on developing northern Australia in 2015 (Australian Government, 2015), a raft of NT and Commonwealth government agencies have worked furiously towards a common goal of 'Developing the North.' The objectives of these development imperatives can nonetheless be slippery, particularly in the underpopulated NT where according to the NT Government a "large undeveloped land mass" has yet to reach its "full potential."1 But typically, the agenda

1 https://business.nt.gov.au/investment-and-major-projects/investment-and-development/northern-australia-development. 
involves the establishment of large-scale mining and petroleum operations, pastoralism, agriculture and aquaculture, and can also involve state exploitation of land, including for defence training purposes, and infrastructure such as housing, dams or roads. Such projects are presented axiomatically as being for the "common good" (Blaser \& de La Cadena, 2017, p. 185), certainly for the NT as a political and economic jurisdiction, but also for Indigenous people who will be lifted from poverty via the jobs, business opportunities and services generated. This paper interrogates the assumptions and knowledge traditions underpinning northern development in an unorthodox way: by mobilising a 'ground up' STS approach to understand how often mundane socio-material objects of development in the north are differentially constituted. Taking the example of gravel, the core constitutive element of much of the NT's road network, I consider how my interlocutors - employees at an NT Aboriginal land council - enact this rocky aggregate as either a legal contract or as a road according to the material, social and textual epistemic practices they deploy (Shapin \& Schaffer, 1985). Absent from this analysis, however, is a third conception of gravel pits as "people-places" (Verran, 2002). In this conception, gravel pits are constituted by Indigenous knowledge practices that recognise the "relations between human beings and other-than-human beings that together make place" (de la Cadena, 2010, p. 356). If we pay attention to the different ways that gravel is enacted, we can begin to recognise what versions of the world are privileged and excluded in the mantra of "Developing the North", opening up the potential for more inclusive development policy.

\section{Gravel as road}

Kevin ${ }^{2}$ walks over to the rust-hued mound and picks up a handful of aggregate. We are an hour's drive south of Darwin, at a spot about 100 metres or so from the road edge, shielded from the road by a ribbon of sparse savannah vegetation. The gravel stockpile Kevin has sampled has been bulldozed to the edge of a 100 metre long by 50 metre wide, and half-metre deep, rectangular scrape, denuded of vegetation, the top few centimetres of overburden pushed aside. It is a gravel pit, and these extractive sites are everywhere, pock-marking road corridors throughout the Northern Territory. It's the third one we've looked at so far today and in it Kevin identifies the best example of the gravel suitable for the resource's primary human purpose - the endless task of scaffolding the Northern Territory's vast unsealed remote road network - the lifelines connecting Indigenous and non-Indigenous communities with larger service centres as well as more heavily-trafficked roads such as the Stuart Highway.

The Northern Territory's road network differs markedly from others in Australia - a cause and effect of its so-called "under-development". Only $25 \%$ of the Northern Territory's $36,000 \mathrm{~km}$ road network is sealed, purportedly putting the Northern Territory behind countries such as Botswana, Togo, Senegal, Tonga and Afghanistan (Smee, 2016). This situation creates a ceaseless dependence on gravel. In the NT, gravel is composed of a particular surface rock found in tropical climes known as "laterite". In the perpetual state of accelerated decay that marks materials in the tropics, laterite turns from rock into gravel through a process of weathering, perfect for road construction when combined with water and compacted. But this quality also makes it eminently unsuitable for this purpose. Every year, monsoonal rains come and wash it away from the surfaces of the unsealed roads, causing corrugation at best, impassability at worst, and necessitating still more gravel as urgently as possible, so that roads can become roads again. It is a circularity which highlights a more-than-human dimension to human efforts. The need for gravel is not just a Northern Territory phenomenon: sand and gravel are "the most extracted group of materials worldwide, exceeding fossil fuels" (Torres 
et al., 2016, p. 970), their over-exploitation arguably as much an environmental concern as their more fixated-upon subterranean relatives such as uranium ore, iron ore, gas or coal. But gravel's role as a foundational substrate of human life typically goes unnoticed.

Figure 1: a demonstration of gravel plasticity

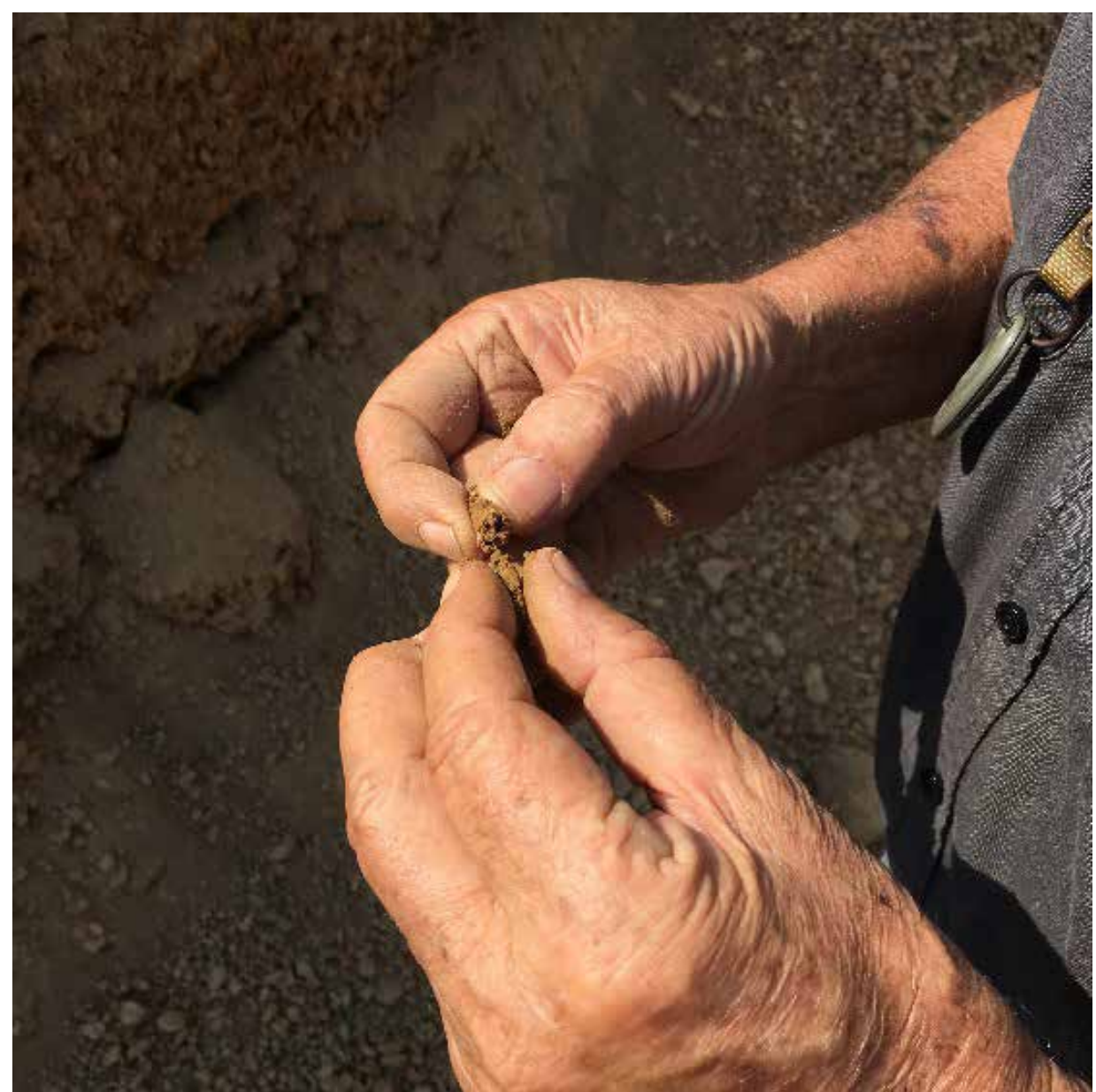

Source: Kirsty Howey

Although he's not an engineer, Kevin is a gravel expert. He has spent much of his life working on the Northern Territory's roads in searing temperatures, living in mobile workers' camps equipped with not much more than a dozer, truck, and generator. All the technical requirements for gravel road-making are in the Northern Territory Government's 256 page engineer-designed road maintenance manual (Northern Territory Department of Infrastructure Planning and Logistics, 2017) but Kevin's work has given him the kind of scientific know-how not easily reduced to writing. He can tell by the presence of the purple-flowered turkey bush that the topsoil is likely to yield quality gravel underneath. Where engineers test using a densometer, the sound emitted by dropping a long-handled shovel tells him whether compacted gravel is the right density for cars. And instead of slavishly following a table of ratios listing the optimum gravel properties, including something called a "plasticity index", Kevin sieves out the larger rocky particles using his fingers to leave a finer gravel aggregate, which he spits into, then rolls the surprisingly doughy mixture between his fingers into a ball before breaking it apart. "Perfect" 
he says. The right plasticity is critical in the tropics for building good roads, he tells me:

You need a little clay to bind it together, but too much it gets slippery and soft. If it's too sandy, on the other hand, it will unravel when it gets wet and you end up with corrugations on the road. Everyone thinks building roads is easy (15 February 2018).

With the hard work of road-building now behind him, Kevin occupies an ambivalent place in the Northern Territory's institutional bureaucratic network - employed as a public servant by a Northern Territory Government department, but now seconded to the Northern Land Council to facilitate land access applications relating to roads on Aboriginal-owned land. There's a reason for this curious arrangement: the Northern Land Council (or NLC) is one of two large Aboriginal land councils in the Northern Territory, created by the Aboriginal Land Rights (Northern Territory) Act (Cth) in 1976. Over half of the land in the NT is now Aboriginal freehold owned under the Act, and the NLC (together with other land councils), is responsible for administering this on behalf of the Traditional Aboriginal Owners of that land. The majority of Indigenous communities are located on Aboriginal land, and so too are the unsealed roads that link them. So to build and maintain many roads in the Northern Territory - indeed, to do anything on Aboriginal land - you need Traditional Owner and land council consent.

Figure 2: Map showing Indigenous property interests in the Northern Territory. Aboriginal land owned under the Land Rights Act is in pale orange. The grey indicates land over which the Federal Court has made a determination of native title.

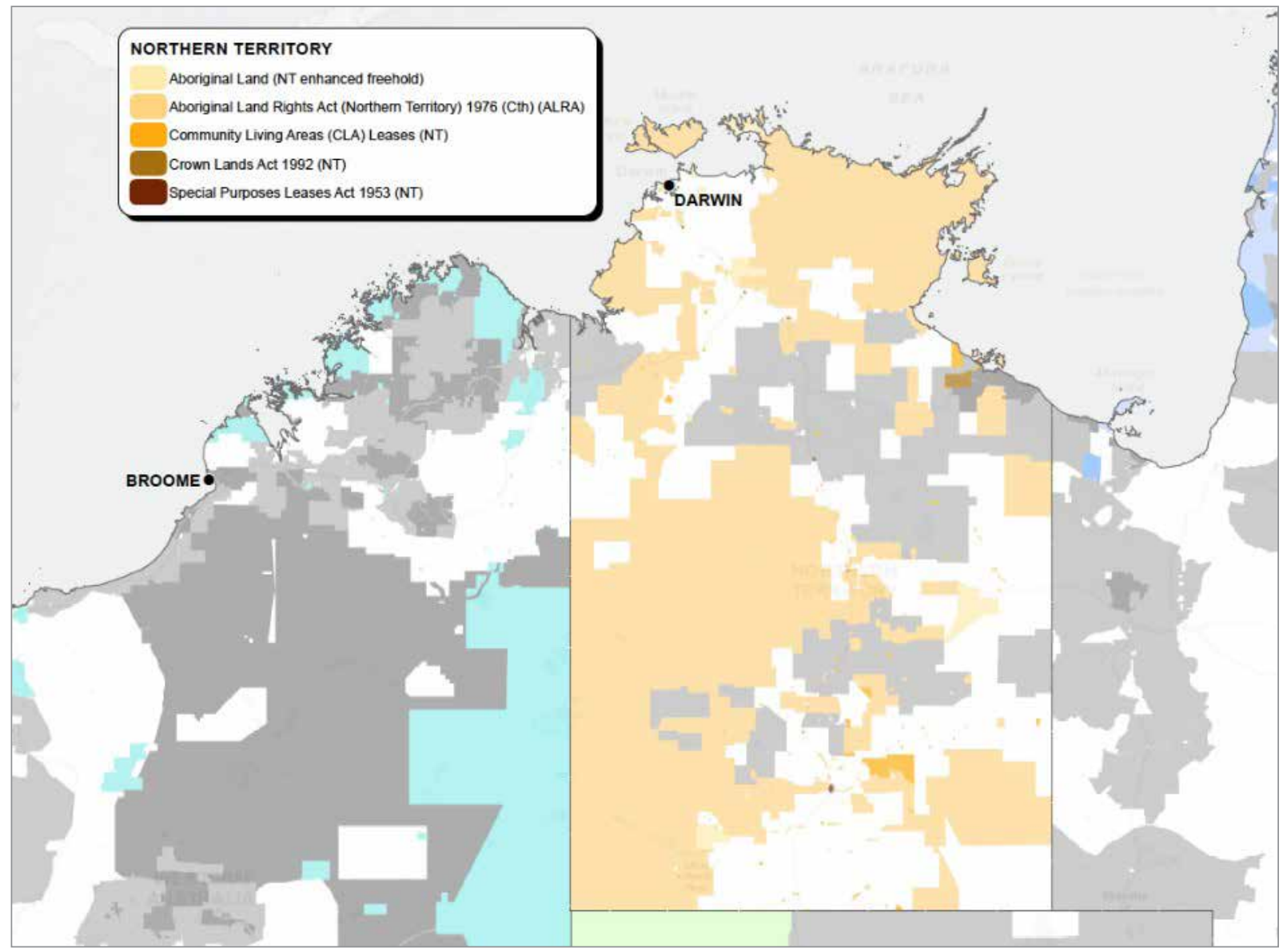

Source: Native Title Tribunal 2016 
While Kevin's knowledge of the properties of gravel is formidable, for him the gravel is a means to an end. The main game is the roads themselves, and movement of people and things along them. For Kevin, the ostensibly dull bureaucratic world of "asset maintenance" to which gravel extraction is directed - which doesn't attract attention or votes like a new road, mine or other development - is a passion. Kevin says his first priority is mobility for Indigenous residents of remote communities, often cut off for long periods during the wet season. Secondary is the idea of roads as conduits for better development in northern Australia. The political ontology of gravel enacted into being (Mol, 2002) as a road is constituted by a various material, social and textual practices (Shapin \& Schaffer, 1985), many of them internal to the NT bureaucracy and only partially accessible to me as a researcher, including through discussions with Kevin in his hybrid government-NLC role. I am using the term "enacted" in the sense described by Annemarie Mol, to acknowledge that differences between gravel "realities" (for example, as a road, or, in the other ways I describe in this article) are not merely a matter of perspective on a single object, but produce gravel as multiple objects (Law \& Singleton, 2005, p. 342; Mol, 2002).

At the political level, NT bureaucrats prepare evidence-based regional infrastructure studies and investment plans in an attempt to persuade their federal counterparts to fund and maintain NT roads, a hard sell given the "vast road network, the low infrastructure base, low traffic volumes and climatic and geographic conditions" when compared to the rest of Australia (Northern Territory Department of Transport, 2017, p. 8). In the NT Department of Infrastructure, engineers and other road experts draw on a wealth of scientific knowledge to carefully develop manuals of the kind Kevin eschews to ensure minimum standards are met, and scrutinise tenders submitted by private contractors to undertake the lucrative work of building and maintaining roads. And the road workers who build the roads themselves develop their own protocols, practices and know-how to ensure that this work is done as efficiently as possible so roads can be reformed after a heavy wet season. Gravel is also a tool to solve the problem of how to build more and better roads in service of larger socio-economic goals that fold "the social and the technical together to produce material rearrangements in the name of emancipatory transformation or 'development'” (Harvey \& Knox, 2015, p. 8). While gravel pits (and the roads they scaffold) often happen to be located on Aboriginal land - requiring entanglement with land council bureaucracy - gravel approvals are grudgingly accepted as part of the machinery necessary to get roads done.

\section{Gravel as contract}

But Kevin's worldview of gravel differs from most of his NLC colleagues. I undertook ethnographic research in the "Section 19 Team" of the NLC, responsible for negotiating agreements for various outsiders to access Aboriginal land across the NLC's vast region. This ethnography, undertaken pursuant to a research agreement with the NLC, involved situating myself in the NLC's head office in Darwin to observe staff go about the day-to-day business of producing agreements, supplemented by semi-structured interviews with those staff, for four months full-time in 2017. I attended the NLC's head office more sporadically for specific interviews with staff during 2018, as well as undertaking field trips to three NLC meetings in remote communities, and to the gravel pits outside of Darwin with Kevin in April 2018.

Instead of the "big" events that frequently discursively characterise development and Indigenous institutions - including about mines, hydraulic fracturing, and other forms of extractive development - my ethnographic focus was on the mundane and routinised 
institutional practices of agreement-making carried out by teams of lawyers, anthropologists, project officers, field staff, and administrative staff. This is in fact where the NLC's encounters with "development" usually occur, through the lens of what are known as "Section 19 agreements". "Section 19" refers to the provision in the Land Rights Act which gives the NLC the power to grant property interests in Aboriginal land, be they leases, licences, or some other form of property tenure. The work of the Section 19 Team, though enormous in volume, does not attract much attention outside the NLC. It involves 'processing' applications for routine land uses - things like cattle grazing, mustering of feral buffalo, operating a community store, constructing public housing, running a health clinic and operating a fishing tour. The Section 19 Team is made up of about 15 mostly Indigenous staff, working furiously to diminish the backlog of land use applications across the top half of the Northern Territory. They too, are experts, but their expertise is different to Kevin's. They are skilled in deal-making under pressure, in collaboration with ever-changing project teams, in mobilizing Traditional Owners across numerous remote sites for consultations, in responding to the inevitable complaints about NLC delay, and in doing all this on a wafer-thin budget. Just like the road workers, all this furious industry is amplified in the four month long dry season when the pressure is on to get things done.

Gravel is not a means to an end for the Section 19 Branch - its extraction is the end of a process culminating in a legal agreement or contract, usually a licence for a specified period governing the licensee's future extractive operations. In the pantheon of unremarkable NLC contracts, the gravel agreement probably ranks the lowest. Despite the clear embodied need for gravel, these agreements are not prized. They are of minimal financial benefit compared with the costs of their administration, processed as quickly as possible using boiler-plate agreement templates. They must be triaged in the context of the wider backlog of applications, which despite the industry of the Section 19 Branch, keeps increasing. Thus, it is not the road which is the primary focus for the Section 19 Branch, but the legal consent to extract the gravel required to fix it: the gravel licence. There are few institutional resources allocated to what happens after the agreement is executed, to ensure that environmental requirements are followed, that the road for which the gravel is intended is resurfaced, that the gravel itself is fit for purpose. "You're that busy chasing your tail or rainbows or whatever we don't have a lot of time to refine our systems," said one interlocutor (12 June 2018). All efforts and resources are temporally focused on agreement-making on a vast geographic scale for a bewildering array of purposes, propelling those involved, and the gravel itself, forward in increasing momentum to a never defined horizon.

My wider research shows how the characteristics of an NLC gravel agreement - which I see as an iteration of a configuration that first came to life during the NLC's negotiation for the Ranger uranium mine nearly 40 years ago - can be seen in all agreements in the NLC's region. This internal configuration is comprised of various institutional practices that "clot" (Verran, 2009) along a relatively simple linear temporal progression commencing with an application to the NLC by a third party to access a land-based resource on Aboriginal land, and ending with the execution of contract by which a property interest is granted to that third party. $A$ number of steps must occur to reach this end point, with tasks performed by various "project team members" within the NLC - a Section 19 project officer assesses the adequacy or reasonableness of the application against certain criteria, a lawyer negotiates the terms and conditions of the contract, an anthropologist compiles a list of Traditional Aboriginal Owners whose consent is required for the property interest to be granted, Section 19 and field officers organise a consultation "out bush" with the listed Traditional Owners about the proposal, 
and a lawyer prepares agenda papers seeking approval of the contract by the relevant NLC delegate. Although its constitutive elements are vulnerable to negotiation and contest within the institution in accordance with institutional power dynamics, this configuration is more or less stable for all agreements at the NLC. Gravel can be substituted for shale gas, iron ore, or uranium ore, although these kinds of extractive industries are sometimes seen as inconsistent with Indigenous relationships to land and for Indigenous peoples' desired futures. Or exchange gravel for more valorised land-uses which are seen to be consistent with Indigenous-led development (Neale, 2011, p. 326) - for example the celebrated new industry of 'carbon farming' using traditional Indigenous fire management techniques. In all cases the arrangement must be secured by an agreement authorised under the Land Rights Act if it occurs on Aboriginal land. Or to move to more mundane and ostensibly apolitical land uses, swap gravel for a flat piece of land in a community for public housing, a police station, or an office for an Indigenous corporation, regardless of the object the process and form of agreement-making is always similar. My observation during field work was that, for an NLC bureaucrat, they are dealt with the same way, using the same routinised processes outlined briefly above that culminate in the production of an agreement. At the NLC, a gravel pit is a uranium mine is a fracking well is a health clinic, these disparate material resources and the social, political and ontological conflicts embedded within them apparently capable of resolution by the abstract universalism of property law.

\section{Gravel as "people-places" - a missing northern development object}

I have explained Kevin's object as the road, and the NLC's object as the agreement, both of these connected within a wider network of associations broadly relating to the use and 'development' of Aboriginal land in the Northern Territory. Gravel is enacted differently due to Kevin and the Section 19 team's differentiated roles, perspectives and epistemic practices. For Kevin, gravel's road-making potential is paramount - whereas for the NLC the material properties of gravel are less important than the fact of it being a land-based resource amongst many others for which access is sought and which must be swiftly "processed" using the NLC's tried and tested agreement configuration. Yet both enactments of gravel surrender to the stated policy objectives of northern development, and to land law as a mechanism to "constitute ... relationships with the ecological networks of particular places and sustain particular values in relation to the more-than-human world" (Van Wagner, 2016, p. 313). In their structuring of relationships that constitute gravel, certain values with respect to the world are thus upheld and reinforced by Kevin's and the NLC's imaginaries.

Yet Van Wagner's quote above hints at a third conception of gravel that is absent or obscured in the preceding analysis. The places that are gravel pits are owned by and lived in by Indigenous people. As socio-material entities, these places are constituted in quite different institutions, alternative and diverse languages, and in disparate knowledge traditions, compared to the gravelly roads and the legal contracts authorising the extraction of gravel for this purpose. In her work on the epistemic differences between Yolnu firing regimes and environmental scientists' "prescribed burning" practices in north-east Arnhem land, Verran calls attention to the Yolnu reality where people and place are in fact one entity, "people-places" that "express and embed immanent relationalities" (Verran, 2002, p. 749). 
North Australian Indigenous ontologies imbue rocks and aggregates with sentience as embodiments of creative beings from whom all life and non-life is descended and governed where rocks can "listen", and indeed "all humans, animals and objects have the potential to be intentional subjects" (Povinelli, 1995, p. 509). Although the NLC is tasked with administering Aboriginal land on behalf of Indigenous landowners, there is only the briefest of temporal openings, or apertures, in the NLC's agreement-making configuration by which such ontologies of gravel have the possibility of being expressed or made visible - that is, through the legally mandated mechanism of obtaining consent or otherwise to gravel pits from Traditional Owners during a consultation. Similarly, while road-workers must comply with the terms and conditions of gravel pit licences, including those mandating the protection of sacred sites, there is little opportunity to engage with or recognise the possibilities of other worldviews of gravel. The focus is on getting roads done, as quickly as possible. But the third gravelly object, as "people-place" - while not clearly visible to Kevin or NLC Section 19 officers - is nonetheless present and "going on" with the other gravelly objects at the same time. Instead of obscuring these relationships via the abstracting universalism of property law and other policy instruments, we should foreground the "complex interdependence of relations between humans and more-than-human interests at stake, as well as the embodied experience of living in particular places" (Van Wagner, 2016, p. 313). This is what is required to undo or begin to reconfigure the unequal way in which rocks like gravel are organised, separated, and allocated by dominant setter-colonial imaginaries (Borrows, 1997, p. 420).

\section{Conclusion}

Paying ethnographic attention to gravel as an object enacted in multiple ways as I have done makes visible what is not obvious discursively: including the materials, exertions, politics and complexities of more mundane socio-material forms of development in northern Australia. Gravel is often obscured as a resource necessary to enact the policy agenda of "Developing the North," its importance usually dwarfed by a focus on other more spectacular projects. Evoking Verran, I suggest here that paying attention to how these different ontologies of gravel - as road, as contract and as "people-place" - are held together yet "abut and abrade" (Verran, 2002, p. 730), and can create postcolonial moments that challenge, interrupt and redistribute the dominant power relations within which we are enmeshed, thereby enabling alternative and more inclusive possibilities for northern development policy. This would require displacing dominant frames of development, and making the space through partnerships and collaborations with Indigenous peoples and institutions for alternative imaginaries to become not only visible, but to inform and structure policy agendas. In sum, all three gravel entities foregrounded in this paper are northern development objects, and all need to be implicated in northern development policy. 
Figure 3: Gravel pit outside Darwin

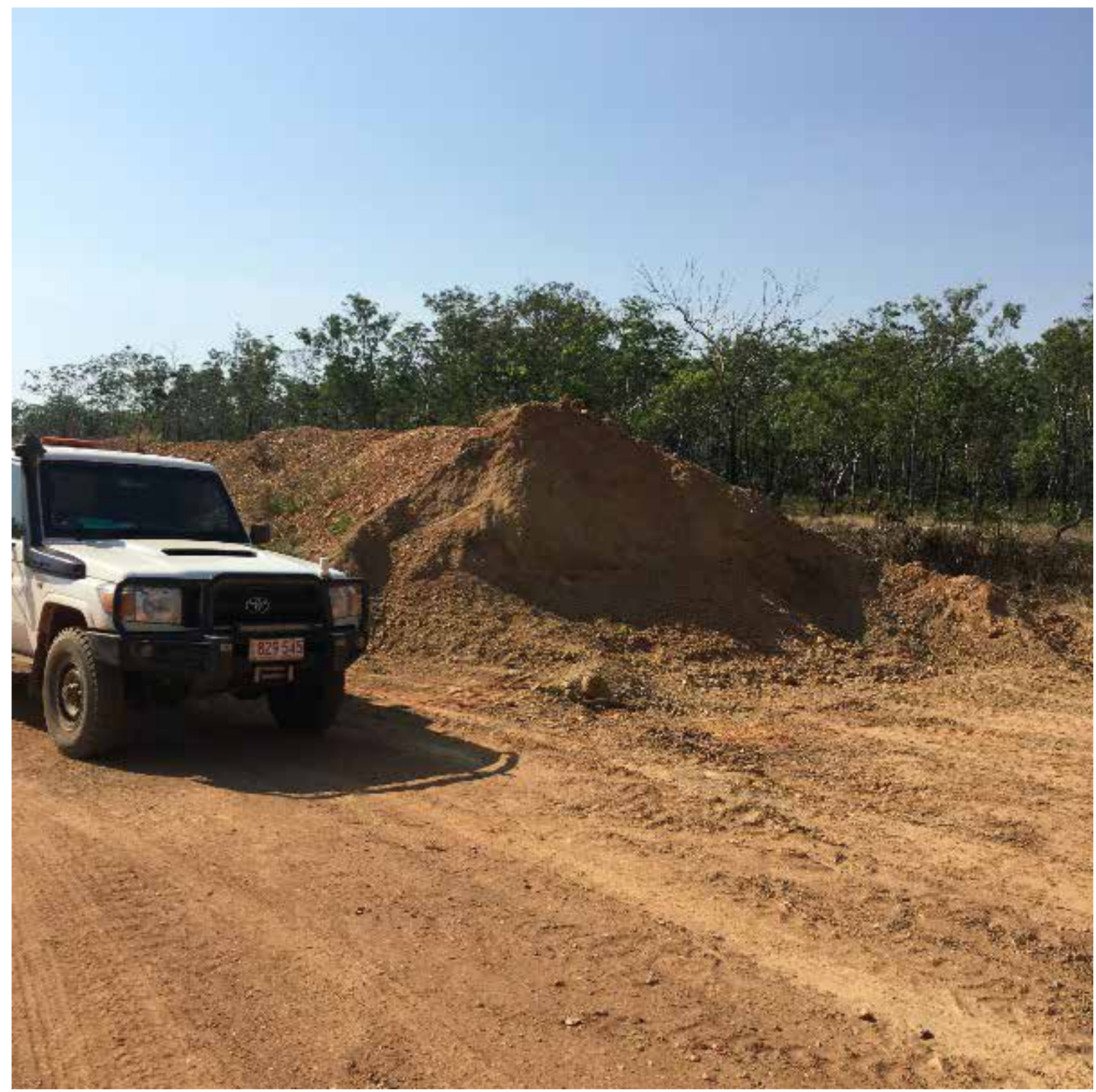

Source: Kirsty Howey

\section{Acknowledgment}

The author would like to acknowledge the Northern Land Council for enabling this research, and the late Dennis Powley and his expertise and knowledge about the challenges of doing development in the tropics. 


\section{References}

Australian Government. (2015). Our North, Our Future: White Paper on Developing Northern Australia. Canberra

Blaser, M., \& de La Cadena, M. (2017). The Uncommons: An Introduction. Anthropologica, 59(2), 185-193. doi:10.3138/anth.59.2.t01

Borrows, J. (1997). Living between water and rocks: First Nations, environmental planning and democracy. University of Toronto Law Journal, 47(4), 417- 468. doi:10.2307/825948

de la Cadena, M. (2010). Indigenous Cosmopolitics in the Andes: Conceptual Reflections Beyond 'Politics'. Cultural Anthropology, 25(2), 334-370. doi: https://doi.org/10.1111/j.1548-1360.2010.01061.x

Harvey, P., \& Knox, H. (2015). Roads: an anthropology of infrastructure and expertise. Ithaca, New York: Cornell University Press.

Law, J., \& Singleton, V. (2005). Object Lessons. Organization, 12(3), 331-355. doi:10.1177/1350508405051270

Mol, A. (2002). The Body Multiple: Ontology in Medical Practice. Durham: Duke University Press.

Neale, T. (2011). Duplicity of Meaning: Wildness, Indigeneity and Recognition in the Wild Rivers Act Debate. Griffith Law Review, 20(2), 310-332.

Northern Territory Department of Infrastructure Planning and Logistics. (2017). 2017 Standard Specification for Road Maintenance. Northern Territory Government. Darwin.

Northern Territory Department of Transport. (2017). NT Roads and Bridges Strategy - Network Investment Plan. Northern Territory Government. Darwin.

Povinelli, E. A. (1995). Do Rocks Listen? The Cultural Politics of Apprehending Australian Aboriginal Labor. American Anthropologist, 97(3), 505-518. doi: https://doi.org/10.1525/aa.1995.97.3.02a00090

Shapin, S., \& Schaffer, S. (1985). Leviathan and the air pump: Hobbes, Boyle, and the experimental life. Princeton, New Jersey: Princeton University Press.

Smee, B. (2016, 18 April). NT road networks on par with the world's poorest nations. NT News. https://www.ntnews.com.au/news/northern-territory/nt-road-networks-on-par-with-wom-of-the-worlds-poorestnations/news-story/fc6da6ed9eb44ccf6594ad51daeeea18

Torres, A., Brandt, J., Lear, K., \& Liu, J. (2016). A looming tragedy of the sand commons. Science, 357(6355), 970-971.

Van Wagner, E. (2016). Law's Rurality: Land Use Law and the Shaping of People-Place Relations in Rural Ontario. Journal of Rural Studies, 47, 311-325. doi:https://doi.org/10.1016/j.jrurstud.2016.01.006

Verran, H. (2002). A postcolonial moment in Science studies: Alternative Firing Regimes of Environmental Scientists and Aboriginal Landowners. Social Studies of Science, 32(5/6), 729-762. doi:https://doi.org/10.1177/030631270203200506

Verran, H. (2009). On Assemblage. Journal of Cultural Economy, 2(1-2), 169-182. 